\title{
Effect of Nitrogen and Potassium Fertilization Doses on Elephant-Grass Genotypes for Energy Purposes
}

\author{
Wanessa Francesconi Stida ${ }^{1}$, Brunno de Oliveira Almeida ${ }^{2}$, Rogério Figueiredo Daher ${ }^{1}$, \\ Cássia Roberta de Oliveira Moraes ${ }^{2}$, Ana Kesia Faria Vidal ${ }^{1}$, Rafael Souza Freitas ${ }^{1}$, Flávio Dessaune Tardin ${ }^{3}$, \\ Bruna Rafaela da Silva Menezes ${ }^{4}$, Eduardo Peres Furlani ${ }^{5} \&$ Marcelo Vivas $^{1}$ \\ ${ }^{1}$ Universidade Estadual do Norte Fluminense Darcy Ribeiro, Brazil \\ ${ }^{2}$ Instituto Capixaba de Pesquisa, Assistência Técnica e Extensão Rural, Brazil \\ ${ }^{3}$ Empresa Brasileira de Pesquisa Agropecuária, Embrapa Milho e Sorgo, Brazil \\ ${ }^{4}$ Universidade Federal Rural do Rio de Janeiro, Brazil \\ ${ }^{5}$ Universidade Federal de Juiz de Fora, Brazil \\ Correspondence: Wanessa Francesconi Stida, Universidade Estadual do Norte Fluminense Darcy Ribeiro, Brazil. \\ E-mail:w.stida@hotmail.com
}

Received: March 5, 2018

doi:10.5539/jas.v10n10p446
Accepted: May 2, $2018 \quad$ Online Published: September 15, 2018

URL: https://doi.org/10.5539/jas.v10n10p446

\begin{abstract}
In view of the current global energy landscape, to develop alternative energy mechanisms to the oil has become essential. For that, biomass as well as the use of elephant-grass present themselves as attractive choices for energy purposes. That culture has a high growth prospect, as it contains characteristics such as high production, biomass quality, and high photosynthetic capacity. The purpose of this work was to assess the response of eight elephant-grass genotypes to nitrogen and potassium fertilization from the evaluation of morpho-agronomic traits. It was used a randomized block experimental design with three replications in the factorial scheme within a subdivided plot composed of principal factor (plots): genotypes and secondary components (subplots): potassium $(2$ levels $) \times$ nitrogen $(3$ levels $)-200 \times 400,200 \times 1000,200 \times 1600,500 \times 400,500 \times 1000$, and $500 \times 1600 \mathrm{~kg}$ $\mathrm{ha}^{-1}$. There was an adjustment of first degree linear model of the regression for all traits in at least one genotype. For DMP, the Capim Cana D'África, CPAC, and IJ 7139 genotypes indicated an inversely proportional response to the increasing of $\mathrm{N}$ in the fertilization. The response according to the $\mathrm{N}$ increasing in the fertilization was directly proportional for the CPAC genotype in relation to the NP, and for the Cana D'África, CPAC, and IJ 7139 genotypes in relation to the ALT. For SD, the CPAC and Vruckwona genotypes showed a positive effect on the increasing doses of $\mathrm{N}$, and the IJ 7139 genotype, a negative correlation. The results are quite promising and ensure the use of the eight elephant-grass genotypes as an alternative source for biomass production.
\end{abstract}

Keywords: bioenergy, linear regression, morpho-agronomic traits, Pennisetum purpureum Schum.

\section{Introduction}

The use of vegetal biomass to produce energy has been of great interest to the researchers, as it is an excellent alternative to the excessive burning of fossil fuels, to combat climate changes and environmental imbalances generated by the high rate of greenhouse gas emissions during the burning. Given that, the elephant-grass has stood out as one of the main species to produce biomass for energy purposes (Morais, Quesada, Reis, Urquiaga, Alves, \& Boddey, 2011), as it produces large amount of biomass and quality to turn it into bioenergy. Those traits when associated to others, such as fiber contents, lignin, and to the relation C:N make this culture an excellent alternative energy source (Mohammed et al., 2015).

For the past years, the elephant-grass biomass has been subject of study, focusing on its utilization as solid fuel, due to its high potential to produce renewable energy and the possibility to be used as an energy renewable source. That is because of its shorter development cycle and its capacity to produce double tones of dry biomass per hectare yearly, when compared to the Eucalyptus, which is the main source used to generate energy by direct combustion (Mckendry, 2002; Marafon, Camara, Santiago, \& Rangel, 2010).

By contrast, together with its high productive potential, the elephant-grass culture has a high nutrient extraction 
from the soil, such as N, K, Ca, and S due to its high dry matter production (Santos et al., 2012).

Nitrogen is an essential constituent of proteins, which participates in the photosynthetic process and plant development concerning height and tiller number; consequently, it contributes to the increasing of the dry matter production of the culture (Bonfim-da-Silva \& Monteiro, 2006). According to Oliveira et al. (2015), the elephant grass crop presents high potential to produce biomass, according to the nitrogen fertilization, in order to meet the growing demand for energy.

Potassium is the cation with the highest concentration in plants and shows relevant physiologic and metabolic functions, such as enzyme activation, photosynthesis, assimilate translocation, nitrogen absorption, and protein synthesis, thus, becoming limiting in systems with intensive use of cultivated soils (Andrade, Fonseca, Queiroz, Salgado, \& Cecon, 2003). This way, nitrogen and potassium play a fundamental role for an adequate fertilization program for the elephant-grass culture.

The nitrogen fertilization is one of the components that most demand energy in agriculture and cattle production, able to achieve up to $50 \%$ of all energy consumed in the agriculture steps of a production system. Thus, the ideal is to produce biomass with high fiber, lignin and cellulose contents, high dry matter production, and low consume of nitrogen fertilizers to this plant provides quality biomass for energy purposes and its energy yield is significantly positive (Borges, Aquino, \& Evangelista, 2016). There are numerous reports in literature about the effects of nitrogen fertilization in elephant-grass; also, strong effects increasing diverse traits, such as dry matter, crude protein, leaf/stem relation, number of tillers, plant height, among others have been shown (Cruz et al., 2010; Santos et al., 2014; Oliveira et al., 2015; Almeida et al., 2016; Novo et al., 2016). However, in order that those effects are evident, there is the need that other factors are not limiting the plant growth, such as climate, soil, vegetation, and others.

The purpose of this work is to assess the effect of different doses of nitrogen and potassium fertilization in morpho-agronomic traits of elephant-grass genotypes in edaphoclimatic conditions in Campos dos Goytacazes city, Rio de Janeiro state, Brazil.

\section{Material and Methods}

The experiment was conducted in an agreement area between the Centro Estadual de Pesquisas em Agroenergia e Aproveitamento de Resíduos, PESAGRO, Rio (Agroenergy and Waste Management State Research Center) and the Universidade Estadual do Norte Fluminense Darcy Ribeiro, UENF (State University of North Fluminense Darcy Ribeiro) located in Campos dos Goytacazes city. The climate is classified as Aw type, tropical hot and humid, with dry season in winter, rainy season in summer and annual precipitation around 1,152 $\mathrm{mm}$ (Köppen, 1948).

The soil is characterized as a yellow latosol soil (Brazilian public agricultural research corporation [Embrapa], 2013) by the following chemical composition: $\mathrm{pH} 5.7$; phosphorus $7.0 \mathrm{mg} \mathrm{dm}$; potassium $121 \mathrm{mg} \mathrm{dm}^{-3}$; calcium $3.8 \mathrm{cmol}_{\mathrm{c}} \mathrm{dm}^{-3}$; magnesium $2.5 \mathrm{cmol}_{\mathrm{c}} \mathrm{dm}^{-3}$; aluminum $0.0 \mathrm{cmol}_{\mathrm{c}} \mathrm{dm}^{-3}$; hydrogen + aluminum $3.6 \mathrm{cmol}_{\mathrm{c}}$ $\mathrm{dm}^{-3}$.

The accessions used in the experiment were selected for presenting superior traits in terms of biomass generations. Genotypes Cubano Pinda (G1), Vruckwona (G2), IAC-Campinas (G3), Capim Cana D’África (G4), Cameroon (G5), CPAC (G6), IJ 7139 (G7), and BAG-86 (G8) were used.

The experiment used randomized block design with three replications (blocks), in a split-plot arrangement consisting of two factors: Factor 1 (plots): genotypes - eight clones; Factor 2 (sub-plots): potassium (two levels) $\times$ nitrogen (five levels) $-200 \times 400,200 \times 1000,200 \times 1600,500 \times 400,500 \times 1000$, and $500 \times 1600 \mathrm{~kg} \mathrm{ha}^{-1}$ of $\mathrm{K} \times \mathrm{N}$ (six combinations).

Each block was composed of eight lines of $12 \mathrm{~m}$ length and spacing $1.5 \mathrm{~mm}$ between lines. The plot was composed of one line, each one divided into subplots of $2 \mathrm{~m}$, with a total of six subplots, which received the treatments (six combinations). It was considered $1.5 \mathrm{~m}^{2}$ within the subplot to remove the samples that would be assessed.

The experiment was conducted on February 12, 2014. The planting chemical fertilization was performed according to the nutritional recommendation for the species and based on the results of the chemical analysis of the soil obtained. During each evaluation cycle, the fertilization was divided into six applications depending on the rainfall. Manual weeding with a hand hoe was chosen to weed between the lines and in the cultivation lines to control invasive plants (Freire et al., 2013).

The plot-leveling cut was made on 03/29/2014 (45 days after planting), the first cut for evaluation was on 
03/10/2015 and the second one, on 03/15/2016.

The following morpho-agronomic traits were evaluated:

a) Dry matter production (DMP), estimated by the product of the dry matter production of the whole plant multiplied by the percentage of the green matter of the plant, and the value obtained converted to $t \mathrm{ha}^{-1}$;

b) Number of tillers per linear meter (NT) obtained by counting the tillers with height greater than $70 \mathrm{~cm}$ contained within the useful area of the sub-subplot just before the evaluation cut;

c) Mean height of the plants (HEI) in m, measured by graduated scale, based on the medium height of the plants in the plot, measured from the soil up to the apex of the upright leaves, just before the evaluation cut;

d) Mean diameter of the stem at the base of plant (DS) - in mm, measured at $10 \mathrm{~cm}$ from ground level by means of a digital caliper just before the evaluation cut.

Statistical analyses were performed with the Genes programs (Cruz, 2013).

\section{Results and Discussion}

With a view to finding a regression model (first degree or Lack of Regression), it was carried out an analysis taking as independent variable the increasing doses of $\mathrm{N}$ and, as dependent variables, the morpho-agronomic traits evaluated.

\subsection{Dry Matter Yield (DMY)}

Regarding Table 1, it could be seen that, only in the second year, there were genotypes that showed statistical significance of regression based on the estimates of mean squares for the regression and deviations of regression applied to DMP. It could also be noted a significant linear effect of first degree in the regression analysis due to the doses of $\mathrm{N}$ within $\mathrm{K} 2\left(500 \mathrm{~kg} \mathrm{ha}^{-1}\right.$ of $\left.\mathrm{K}_{2} \mathrm{O}\right)$ for IAC-Campinas (G3), CPAC (G6), and IJ7139 (G7) genotypes with their respective coefficients of determination: $98.26 \%$; $91.58 \%$, and $84.34 \%$.

When assessing the DMP in function of the nitrogen fertilization, Santos et al. (2014) noticed an adjustment of second degree linear model at $5 \%$ level significance by means of the $\mathrm{F}$ test to show the increasing trend in the dry matter production of the elephant-grass, according to the increasing doses of nitrogen. Likewise, Oliveira et al. (2015), when studying the effect of increasing doses of $\mathrm{N}$ in the fertilization of six elephant-grass genotypes, observed an adjustment of second degree linear model for the Cameroon-Piracicaba genotype, which presented maximum production of $57.95 \mathrm{tha}^{-1}$ for a dosage of $1600 \mathrm{~kg} \mathrm{ha}^{-1}$ of $\mathrm{N}$.

On the other hand, Figure 1 shows that, for the genotypes in which adjusted regression model was obtained (G4, G6, G7), their highest dry matter production (51.94; 50.70; and $\left.55.10 \mathrm{t} \mathrm{h}^{-1}\right)$ occurred when applying the lowest dose of $\mathrm{N}$. That is, in general, concerning the dry matter production, it was observed there was a trend for the genotype to respond, in an inversely proportional way, to the increment of $\mathrm{N}$ in the fertilization. By performing an analysis of the DMP mean values of the eight genotypes at each dose of $\mathrm{N}\left(400,1000\right.$, and $\left.1600 \mathrm{~kg} \mathrm{ha}^{-1}\right)$ during the two evaluation years, it was possible to notice the decreasing response of genotypes, which DMP values for $\mathrm{N} 1, \mathrm{~N} 2$, and $\mathrm{N} 3$ are $34.87 ; 32.15$, and $28.62 \mathrm{tha}^{-1}$ for the first cut, and $44.15 ; 40.07$, and $38.45 \mathrm{tha}^{-1}$ for the second cut.

The biomass production capacity is one of the most relevant traits to be assessed in the elephant-grass culture. However, by the results obtained, it could be seen that the goal to achieve higher dry matter production was accomplished when applying the smallest dose of $\mathrm{N}$ for fertilization $\left(400 \mathrm{~kg} \mathrm{ha}^{-1}\right)$. Those results confirm the ones found by Novo et al. (2016). When working with increasing doses of $\mathrm{N}$ and $\mathrm{K}$, they observed that as the nitrogen dose associated with the potassium doses was increased, the production was not increased but suppressed. 
Table 1. Estimates of mean squares for the sources of variation due to the regression and the deviation of regression for the first degree linear models for dry matter production (DMP), covering eight elephant-grass genotypes under different nitrogen $\left(\mathrm{N} 1=400, \mathrm{~N} 2=1000, \mathrm{~N} 3=1600 \mathrm{~kg} \mathrm{ha}^{-1}\right.$ of $\left.\mathrm{N}\right)$ and potassium doses $(\mathrm{K} 1=$ 200 and $\mathrm{K} 2=500 \mathrm{~kg} \mathrm{ha}^{-1}$ of $\mathrm{K}_{2} \mathrm{O}$ ) throughout two-year cultivation for energy purposes

\begin{tabular}{|c|c|c|c|c|c|c|c|c|c|c|}
\hline \multirow{3}{*}{ Genotypes } & \multirow{3}{*}{$\mathrm{K}$ doses } & & \multicolumn{8}{|c|}{ PMS } \\
\hline & & & \multicolumn{4}{|c|}{ First cut } & \multicolumn{4}{|c|}{ Second cut } \\
\hline & & & DF & $1^{\text {st }}$ Degree & $\mathrm{R}^{2}(\%)$ & Model & DF & $1^{\text {st }}$ Degree & $\mathrm{R}^{2}(\%)$ & Model \\
\hline \multirow[t]{4}{*}{ Cubano de Pinda } & K1 & Reg & 1 & 21.91 & & & 1 & 356.30 & & \\
\hline & & Dev & 1 & 6.74 & 78.48 & - & 1 & 89.94 & 79.85 & - \\
\hline & $\mathrm{K} 2$ & Reg & 1 & 347.90 & & & 1 & 149.10 & & \\
\hline & & Dev & 1 & 14.01 & 96.12 & - & 1 & 325.50 & 31.42 & - \\
\hline \multirow[t]{4}{*}{ Vruckwona } & $\mathrm{K} 1$ & Reg & 1 & 65.66 & & & 1 & 305.50 & & \\
\hline & & Dev & 1 & $294.20^{*}$ & 18.24 & - & 1 & 323.20 & 48.59 & - \\
\hline & $\mathrm{K} 2$ & Reg & 1 & 226.20 & & & 1 & 32.83 & & \\
\hline & & Dev & 1 & 331.70 & 40.54 & - & 1 & $897.10^{*}$ & 3.53 & - \\
\hline \multirow[t]{4}{*}{ IAC-Campinas } & K1 & Reg & 1 & 31.43 & & & 1 & 156.60 & & \\
\hline & & Dev & 1 & 192.80 & 14.02 & - & 1 & 7.04 & 95.7 & - \\
\hline & $\mathrm{K} 2$ & Reg & 1 & 31.85 & & & 1 & 301.70 & & -1 \\
\hline & & Dev & 1 & 57.34 & 35.71 & - & 1 & 161.90 & 65.07 & - \\
\hline \multirow[t]{4}{*}{ Capim Cana D’África } & $\mathrm{K} 1$ & Reg & 1 & 55.25 & & & 1 & 0.10 & & \\
\hline & & Dev & 1 & 50.97 & 52.01 & - & 1 & 260.80 & 0.04 & - \\
\hline & $\mathrm{K} 2$ & Reg & 1 & 0.53 & & & 1 & $429.20^{*-}$ & & \\
\hline & & Dev & 1 & 70.68 & 0.74 & - & 1 & 7.56 & 98.26 & 1 \\
\hline \multirow[t]{4}{*}{ Cameroon } & $\mathrm{K} 1$ & Reg & 1 & 18.88 & & & 1 & 312.20 & & \\
\hline & & Dev & 1 & 21.23 & 47.06 & - & 1 & 180.80 & 63.33 & - \\
\hline & $\mathrm{K} 2$ & Reg & 1 & 352.40 & & & 1 & 263.30 & & 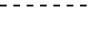 \\
\hline & & Dev & 1 & 186.50 & 65.38 & - & 1 & 77.73 & 77.20 & - \\
\hline \multirow[t]{4}{*}{ CPAC } & $\mathrm{K} 1$ & Reg & 1 & 173.10 & & & 1 & 217.3 & & \\
\hline & & Dev & 1 & 3.96 & 97.76 & - & 1 & 97.45 & 69.03 & - \\
\hline & $\mathrm{K} 2$ & Reg & 1 & 110.30 & & & 1 & $654.80^{*}$ & & \\
\hline & & Dev & 1 & 222.90 & 33.10 & - & 1 & 60.18 & 91.58 & 1 \\
\hline \multirow[t]{4}{*}{ IJ 7139} & $\mathrm{~K} 1$ & Reg & 1 & 181.80 & & & 1 & 109.20 & & \\
\hline & & Dev & 1 & 2.82 & 98.47 & - & 1 & 628.80 & 14.80 & - \\
\hline & $\mathrm{K} 2$ & Reg & 1 & 87.60 & & & 1 & $1268.00^{*}$ & & \\
\hline & & Dev & 1 & 104.50 & 45.60 & - & 1 & 325.50 & 84.33 & 1 \\
\hline \multirow[t]{4}{*}{ BAG-86 } & $\mathrm{K} 1$ & Reg & 1 & 0.31 & & & 1 & 532.60 & & \\
\hline & & Dev & 1 & 194.10 & 0.16 & - & 1 & 322.60 & 62.27 & - \\
\hline & $\mathrm{K} 2$ & Reg & 1 & 32.81 & & & 1 & 8.29 & & \\
\hline & & Dev & 1 & 363.45 & 8.25 & - & 1 & 128.80 & 6.04 & - \\
\hline
\end{tabular}

Note. $*=$ Significant at $5 \%$ level probability by $\mathrm{F}$ test. Overall mean for the DMP-31.89 $\mathrm{t} \mathrm{ha}^{-1}$ trait (first cut) and $40.89 \mathrm{t} \mathrm{ha}^{-1}$ (second cut). 


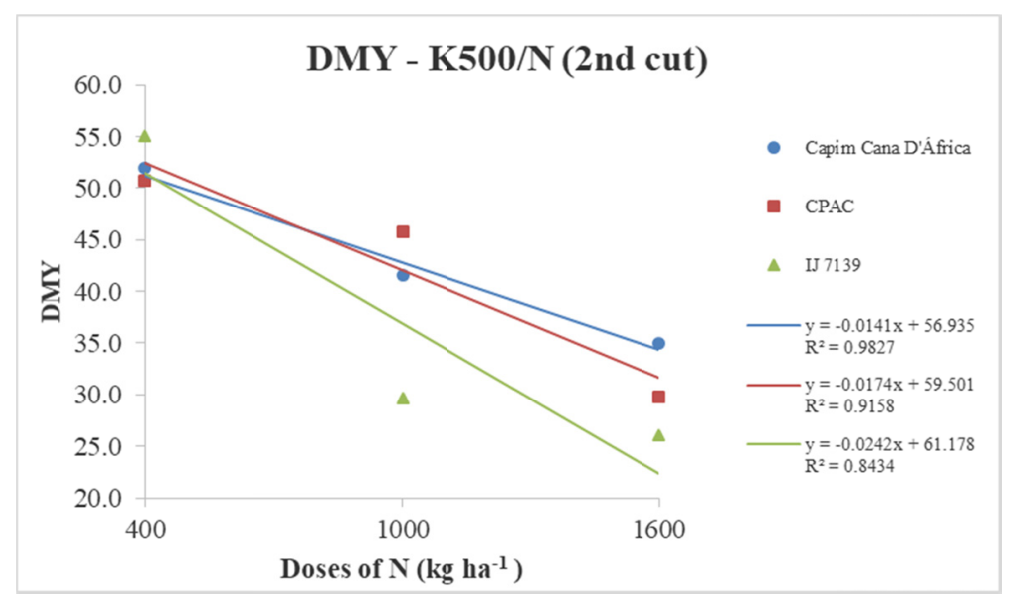

Figure 1. Lines of regression for the DMP trait of the Capim Cana D'África (G4), CPAC (G6), and IJ 7139 (G7) genotypes exposed to fertilization in increasing doses of $\mathrm{N}\left(400,1000\right.$, and $1600 \mathrm{~kg} \mathrm{ha}^{-1}$ of $\left.\mathrm{N}\right)$ within the doses of $500 \mathrm{~kg} \mathrm{ha}^{-1}$ of $\mathrm{K}_{2} \mathrm{O}$ for cut 2

The overall mean for the first and second cuts was 31.89 and 40.89, respectively (Table 1). According to Quesada, Boddey, Reis, and Urquiaga (2004), among the different accessions of the elephant-grass, some of them stand out regarding their high biomass production and high fiber contents. As stated by him, the dry matter production trait achieved values of up to $30 \mathrm{tha}^{-1}$ in eight months, without applying $\mathrm{N}$-fertilizer. The same way, Botrel, Pereira, and Freitas (2000) found annual mean productivity of $31 \mathrm{t} \mathrm{ha}^{-1}$ year ${ }^{-1}$ of dry matter. Those results assert the good selection of elephant-grass varieties that has been performed for high biomass production and the use as an alternative energy source. That provides positive results that ensure the use of the elephant-grass as an alternative energy source by the direct burning of biomass.

In a general comparison between the two cuts, it can be noticed that the dry matter production in the first cut was lower than in the second year of evaluation. In accordance with Table 2, the pluviometric index obtained throughout the experiment was 604.9 and $832.5 \mathrm{~mm}$, in the first and second year, respectively. Tcacenco et al. (1994) state that the elephant-grass culture reaches its optimal development in places where pluviometric precipitation is higher than $1000 \mathrm{~mm}_{\text {year }}{ }^{-1}$. When considering a 7-month period (from August 2014 to January 2015), the accumulated precipitation was of only $181.4 \mathrm{~mm}$, that is, plants were more than half first period of cultivation under water deficit.

Therefore, that water limitation, which is an essential factor for production and development of the culture, could have negatively interfere with its development during all experiment and with the traits evaluated throughout both cuts. In the opinion of Barreto, Lira, Santos, and Dubeux Júnior (2001), decreased leaf expansion, acceleration in foliar senescence rate, inhibition of tillering and branches, and delay in growth and development of the plant are aspects affected by the water deficit.

The increase of DMY content with the development of forage plants is due to the structural changes in tissues, metabolism and transformations of photo assimilation of the leaves to the fruits and other organs of the plant (Mendonça \& Rocha, 1985). 
Table 2. Monthly precipitation recorded between March 2014 and March 2016. Evapotranspirometric Station of Pesagro/Rio, Campos dos Goytacazes, Rio de Janeiro state

\begin{tabular}{llll}
\hline \multirow{2}{*}{ Months } & \multicolumn{3}{c}{ Precipitation $(\mathrm{mm})$} \\
\cline { 2 - 4 } January & 2014 & 2015 & 2016 \\
February & - & 0.0 & 131.1 \\
March & - & 40.3 & 81.6 \\
April & 14.3 & 110.0 & 61.6 \\
May & 103.1 & 42.0 & \\
June & 25.7 & 108.8 & \\
July & 30.8 & 49.0 & \\
August & 139.6 & 18.0 & \\
September & 14.2 & 23.8 & \\
October & 8.1 & 81.7 & \\
November & 17.7 & 57.9 & \\
December & 69.1 & 95.7 & \\
\hline
\end{tabular}

\subsection{Number of Tillers per Linear Meter (NT)}

With regard to the NT trait, the CPAC (G6) genotype was the only one among the others to show regression significance due to the doses of $\mathrm{N}$ within the $\mathrm{K} 1$ dose of $200 \mathrm{~kg} \mathrm{ha}^{-1}$ of $\mathrm{K}_{2} \mathrm{O}$ (Table 3). That genotype also displayed adjustment of first degree linear model $\left(\hat{y}=17.2777+19.7222 \times 10^{-3} \mathrm{~N}, \mathrm{R}^{2}=98.53 \%\right)$ in the second cycle of evaluation (Figure 2).

The overall means were of 32.74 and 38.85 tillers per linear meter for the first and second cuts, respectively (Table 3). Similarly, Santos et al. (2014) obtained 30.67 tillers to the dose of $1000 \mathrm{~kg} \mathrm{ha}^{-1}$ of N and 31.75 tillers per linear meter in the dose of $500 \mathrm{~kg} \mathrm{ha}^{-1}$ of $\mathrm{N}$ for genotypes evaluated at 180 days and at 10 months, respectively. On the other hand, Oliveira et al. (2013) noticed mean of 13.24 tiller for 73 elephant-grass genotypes evaluated at six-month age.

According to Novo et al. (2016), the most productive individuals and that produce a high number of tillers tend to have higher levels of dry matter, cellulose and nitrogen. 
Table 3. Estimates of mean squares for the sources of variation due to the regression and to the deviations of regression for the first degree linear models for number of tillers (NT) concerning eight elephant-grass genotypes under different nitrogen $\left(\mathrm{N} 1=400, \mathrm{~N} 2=1000, \mathrm{~N} 3=1600 \mathrm{~kg} \mathrm{ha}^{-1}\right.$ of $\left.\mathrm{N}\right)$ and potassium doses $(\mathrm{K} 1=200$ and $\mathrm{K} 2$ $=500 \mathrm{~kg} \mathrm{ha}^{-1}$ of $\mathrm{K}_{2} \mathrm{O}$ ) throughout two-year cultivation for energy purposes

\begin{tabular}{|c|c|c|c|c|c|c|c|c|c|c|}
\hline \multirow{3}{*}{ Genotypes } & \multirow{3}{*}{$\mathrm{K}$ doses } & & \multicolumn{8}{|c|}{ NT } \\
\hline & & & \multicolumn{4}{|c|}{ First cut } & \multicolumn{4}{|c|}{ Second cut } \\
\hline & & & DF & $1^{\text {st }}$ Degree & $\mathrm{R}^{2}(\%)$ & Model & $\mathrm{DF}$ & $1^{\text {st }}$ Degree & $\mathrm{R}^{2}(\%)$ & Model \\
\hline \multirow[t]{4}{*}{ Cubano de Pinda } & K1 & Reg & 1 & 13.50 & & - & 1 & 0.17 & & - \\
\hline & & Dev & 1 & 24.50 & 35.52 & - & 1 & 6.72 & 2.42 & - \\
\hline & $\mathrm{K} 2$ & Reg & 1 & 80.66 & & - & 1 & 4.16 & & - \\
\hline & & Dev & 1 & 43.55 & 64.93 & - & 1 & 312.50 & 1.31 & - \\
\hline \multirow[t]{4}{*}{ Vruckwona } & $\mathrm{K} 1$ & Reg & 1 & 80.67 & & - & 1 & 253.50 & & - \\
\hline & & Dev & 1 & 430.20 & 15.79 & - & 1 & 112.50 & 69.26 & - \\
\hline & $\mathrm{K} 2$ & Reg & 1 & 2.66 & & - & 1 & 1.50 & & - \\
\hline & & Dev & 1 & 256.80 & 1.02 & - & 1 & 68.05 & 2.15 & - \\
\hline \multirow[t]{4}{*}{ IAC-Campinas } & $\mathrm{K} 1$ & Reg & 1 & 4.17 & & - & 1 & 54.00 & & - \\
\hline & & Dev & 1 & 220.50 & 1.85 & - & 1 & 8.00 & 87.09 & - \\
\hline & $\mathrm{K} 2$ & Reg & 1 & 4.16 & & - & 1 & 166.60 & & - \\
\hline & & Dev & 1 & 6.72 & 38.26 & - & 1 & 37.55 & 87.65 & - \\
\hline \multirow[t]{4}{*}{ Capim Cana D’África } & K1 & Reg & 1 & 160.20 & & - & 1 & 88.16 & & - \\
\hline & & Dev & 1 & 144.50 & 52.57 & - & 1 & 93.38 & 48.56 & - \\
\hline & $\mathrm{K} 2$ & Reg & 1 & 6.00 & & - & 1 & 192.60 & & - \\
\hline & & Dev & 1 & 8.00 & 42.86 & - & 1 & 43.55 & 81.56 & - \\
\hline \multirow[t]{4}{*}{ Cameroon } & K1 & Reg & 1 & 20.17 & & - & 1 & 37.50 & & - \\
\hline & & Dev & 1 & 84.50 & 19.26 & - & 1 & 93.38 & 28.65 & - \\
\hline & $\mathrm{K} 2$ & Reg & 1 & 0.17 & & - & 1 & 2.66 & & - \\
\hline & & Dev & 1 & 2.72 & 5.76 & - & 1 & $430.20^{*}$ & 0.61 & - \\
\hline \multirow[t]{4}{*}{ CPAC } & K1 & Reg & 1 & 268.70 & & - & 1 & $840.10^{*}$ & & - \\
\hline & & Dev & 1 & 1.99 & 99.25 & - & 1 & 12.50 & 98.53 & 1 \\
\hline & $\mathrm{K} 2$ & Reg & 1 & 6.00 & & - & 1 & 20.16 & & - \\
\hline & & Dev & 1 & 138.80 & 4.14 & - & 1 & 254.50 & 7.08 & - \\
\hline \multirow[t]{4}{*}{ IJ 7139} & $\mathrm{~K} 1$ & Reg & 1 & 13.50 & & - & 1 & 20.16 & & - \\
\hline & & Dev & 1 & 249.40 & 5.13 & - & 1 & 156.00 & 11.44 & - \\
\hline & $\mathrm{K} 2$ & Reg & 1 & 10.66 & & - & 1 & 150.00 & & - \\
\hline & & Dev & 1 & 0.88 & 92.31 & - & 1 & 26.88 & 84.79 & - \\
\hline \multirow[t]{4}{*}{ BAG-86 } & K1 & Reg & 1 & 13.50 & & - & 1 & 121.50 & & - \\
\hline & & Dev & 1 & $501.40^{*}$ & 2.62 & - & 1 & 60.50 & 66.75 & - \\
\hline & $\mathrm{K} 2$ & Reg & 1 & 4.17 & & - & 1 & 8.16 & & - \\
\hline & & Dev & 1 & $501.40^{*}$ & 0.82 & & 1 & 0.05 & 99.32 & \\
\hline
\end{tabular}

Note. $*$ Significant at $5 \%$ level probability by F test. Overall mean for the NT-32.74 (first cut) and 38.85 (second cut). 


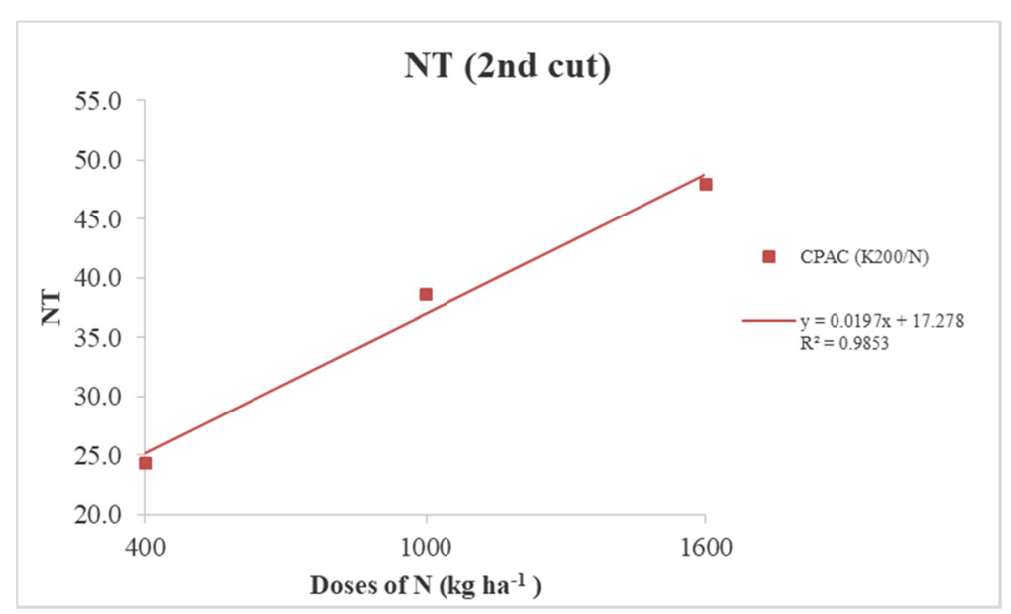

Figure 2. Regression line for the NT trait of G6 - CPAC (G6) genotype, exposed to fertilization in increasing doses of $\mathrm{N}\left(400,1000\right.$, and $1600 \mathrm{~kg} \mathrm{ha}^{-1}$ of $\left.\mathrm{N}\right)$ within the dose of $200 \mathrm{~kg} \mathrm{ha}^{-1}$ of $\mathrm{K}_{2} \mathrm{O}$ in the cut 2

\subsection{Mean Height of the Plants (HEI)}

For the HEI trait, it was noted by the estimates of the mean squares due to regression that, in the first-year evaluation, there was significance of first degree models (Table 4) adjusted to the mean values of the genotypes in function of the doses of $\mathrm{N}$ within $\mathrm{K}$ for the Capim Cana D'África $\left(\hat{\mathrm{y}}=2.7083+4.8611 \times 10^{-4} \mathrm{~N}, \mathrm{R}^{2}=\right.$ $85.46 \%), \operatorname{CPAC}\left(\hat{\mathrm{y}}=3.0666+2.7778 \times 10^{-4} \mathrm{~N}, \mathrm{R}^{2}=82.42 \%\right)$, and IJ7139 $\left(\hat{\mathrm{y}}=2.9888+2.5 \times 10^{-4} \mathrm{~N}, \mathrm{R}^{2}=\right.$ $98.38 \%$ ) genotypes (Figure 3 ).

The overall mean for the first and second cuts was of 3.32 and $3.03 \mathrm{~m}$, respectively (Table 4). In accordance with Santos, Silva, and Queiroz Filho (2001), a greater elongation of the stem, as a defense mechanism of the plants, was seen during a period of water stress probably in function of the leaf area reduction (Table 2). In Figure 3, the Capim Cana D'África (G4), CPAC (G6), and IJ 7139 (G7) genotypes responded positively to the increasing of N in the fertilization at the first-year evaluation. Despite observing that the HEI of the genotypes was not influenced by the doses of $\mathrm{N}$ for five genotypes, the values are close to the ones found by other authors. When noticing six genotypes exposed to nitrogen fertilization in increasing doses of $\mathrm{N}(100,200,400,800$, and 1600 $\mathrm{kg} \mathrm{ha}^{-1}$ ), Oliveira et al. (2015) noticed an overall mean of $3.54 \mathrm{~m}$. 
Table 4. Estimates of mean squares for the sources of variation due to the regression and the deviation of regression for the first degree linear models for height (HEI) concerning eight elephant-grass genotypes under different nitrogen $\left(\mathrm{N} 1=400, \mathrm{~N} 2=1000, \mathrm{~N} 3=1600 \mathrm{~kg} \mathrm{ha}^{-1}\right.$ of $\left.\mathrm{N}\right)$ and potassium doses $(\mathrm{K} 1=200$ and $\mathrm{K} 2=500$ $\mathrm{kg} \mathrm{ha}^{-1}$ of $\mathrm{K}_{2} \mathrm{O}$ ) throughout two-year cultivation for energy purposes

\begin{tabular}{|c|c|c|c|c|c|c|c|c|c|c|}
\hline \multirow{3}{*}{ Genotypes } & \multirow{3}{*}{$\mathrm{K}$ doses } & & \multicolumn{8}{|c|}{ HEI } \\
\hline & & & \multicolumn{4}{|c|}{ First cut } & \multicolumn{4}{|c|}{ Second cut } \\
\hline & & & DF & $1^{\text {st }}$ Degree & $\mathrm{R}^{2}(\%)$ & Model & DF & $1^{\text {st }}$ Degree & $\mathrm{R}^{2}(\%)$ & Model \\
\hline \multirow[t]{4}{*}{ Cubano de Pinda } & K1 & Reg & 1 & 0.015 & & - & 1 & 0.015 & & - \\
\hline & & Dev & 1 & 0.035 & 29.67 & - & 1 & 0.009 & 62.79 & - \\
\hline & $\mathrm{K} 2$ & Reg & 1 & 0.081 & & - & 1 & 0.000 & & - \\
\hline & & Dev & 1 & 0.002 & 97.35 & - & 1 & 0.055 & 0.00 & - \\
\hline \multirow[t]{4}{*}{ Vruckwona } & $\mathrm{K} 1$ & Reg & 1 & 0.010 & & - & 1 & 0.002 & & - \\
\hline & & Dev & 1 & 0.001 & 89.28 & - & 1 & 0.027 & 5.77 & - \\
\hline & $\mathrm{K} 2$ & Reg & 1 & 0.003 & & - & 1 & 0.001 & & - \\
\hline & & Dev & 1 & 0.007 & 35.52 & - & 1 & 0.000 & 74.99 & - \\
\hline \multirow[t]{4}{*}{ IAC-Campinas } & $\mathrm{K} 1$ & Reg & 1 & 0.030 & & - & 1 & 0.010 & & - \\
\hline & & Dev & 1 & 0.001 & 96.43 & - & 1 & 0.010 & 48.07 & - \\
\hline & $\mathrm{K} 2$ & Reg & 1 & 0.006 & & - & 1 & 0.000 & & - \\
\hline & & Dev & 1 & 0.020 & 25.00 & - & 1 & 0.000 & 74.99 & - \\
\hline \multirow[t]{4}{*}{ Capim Cana D’África } & K1 & Reg & 1 & 0.010 & & - & 1 & 0.050 & & - \\
\hline & & Dev & 1 & 0.0001 & 98.68 & - & 1 & 0.003 & 93.55 & - \\
\hline & $\mathrm{K} 2$ & Reg & 1 & $0.510^{*-}$ & & - & 1 & 0.003 & & - \\
\hline & & Dev & 1 & 0.080 & 85.46 & 1 & 1 & 0.003 & 51.92 & - \\
\hline \multirow[t]{4}{*}{ Cameroon } & K1 & Reg & 1 & 0.060 & & - & 1 & 0.060 & & - \\
\hline & & Dev & 1 & 0.050 & 51.92 & - & 1 & 0.020 & 75.00 & - \\
\hline & $\mathrm{K} 2$ & Reg & 1 & 0.010 & & - & 1 & 0.015 & & - \\
\hline & & Dev & 1 & 0.003 & 74.99 & - & 1 & 0.008 & 62.79 & - \\
\hline \multirow[t]{4}{*}{ CPAC } & $\mathrm{K} 1$ & Reg & 1 & $0.167^{*}$ & & - & 1 & 0.001 & & - \\
\hline & & Dev & 1 & 0.035 & 82.42 & 1 & 1 & 0.000 & 74.99 & - \\
\hline & $\mathrm{K} 2$ & Reg & 1 & 0.010 & & - & 1 & 0.000 & & - \\
\hline & & Dev & 1 & 0.023 & 30.73 & - & 1 & 0.016 & 2.41 & - \\
\hline \multirow[t]{4}{*}{ IJ 7139} & $\mathrm{~K} 1$ & Reg & 1 & $0.135^{*}$ & & - & 1 & 0.001 & & - \\
\hline & & Dev & 1 & 0.002 & 98.38 & 1 & 1 & 0.002 & 42.85 & - \\
\hline & $\mathrm{K} 2$ & Reg & 1 & 0.0004 & & - & 1 & 0.041 & & - \\
\hline & & Dev & 1 & 0.0112 & 3.57 & - & 1 & 0.005 & 89.28 & - \\
\hline \multirow[t]{4}{*}{ BAG-86 } & $\mathrm{K} 1$ & Reg & 1 & 0.070 & & - & 1 & 0.020 & & - \\
\hline & & Dev & 1 & 0.003 & 95.30 & - & 1 & 0.011 & 64.47 & - \\
\hline & $\mathrm{K} 2$ & Reg & 1 & 0.150 & & - & 1 & 0.000 & & - \\
\hline & & Dev & 1 & 0.050 & 75.00 & - & 1 & 0.002 & 0.00 & - \\
\hline
\end{tabular}

Note. $*$ = Significant at $5 \%$ level probability by $\mathrm{F}$ test. Overall mean for the HEI-3.32 $\mathrm{m}$ (first cut) and $3.02 \mathrm{~m}$ (second cut). 


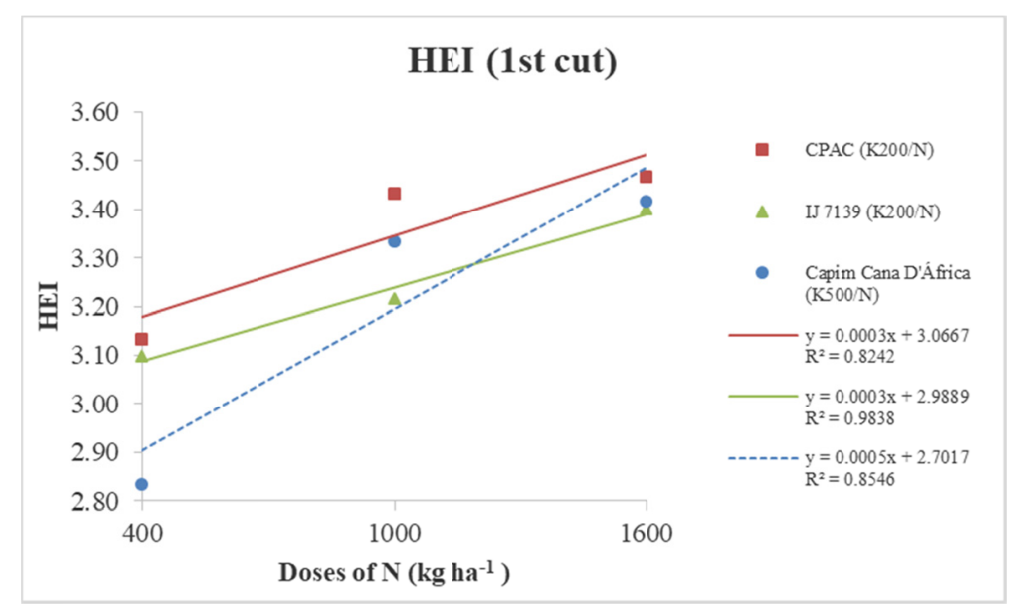

Figure 3. Regression lines for the HEI trait of genotypes that displayed adjustment of first degree linear model according to study of the increasing doses of $\mathrm{N}\left(400,1000\right.$, and $1600 \mathrm{~kg} \mathrm{ha}^{-1}$ of $\left.\mathrm{N}\right)$ within the dose $200 \mathrm{~kg} \mathrm{ha}^{-1}$ of

$\mathrm{K}_{2} \mathrm{O}$ (G6 - CPAC and G7-IJ7139) and within the dose $500 \mathrm{~kg} \mathrm{ha}^{-1}$ of $\mathrm{K}_{2} \mathrm{O}$ (G4 —Capim Cana D'África) in the cut 1

\subsection{Mean Diameter of the Stem at the Base of Plant (DS)}

Regarding the DS trait, there was significance of first degree models adjusted to the mean values of the genotypes according to the doses of $\mathrm{N}$ within $\mathrm{K}$ in the first cut for the CPAC $\left(\hat{\mathrm{y}}=1.34661+3.0694 \times 10^{-4} \mathrm{~N}, \mathrm{R}^{2}\right.$ $=91.82 \%)$ genotype within the K1 dose and in the second cut for the Vruckwona $\left(\hat{\mathrm{y}}=1.6588+3.2222 \times 10^{-4} \mathrm{~N}\right.$, $\left.\mathrm{R}^{2}=78.22 \%\right)$ genotypes in the $\mathrm{K} 1$ dose and IJ $7139\left(\hat{\mathrm{y}}=1.6588+3.2222 \times 10^{-4} \mathrm{~N}, \mathrm{R}^{2}=92,86 \%\right)$ in $\mathrm{K} 2$ dose (Table 5 and Figure 4).

As stated by Daher et al. (2004), the traits number of tillers per linear meter and diameter of tillers, could explain the potential of dry matter production acting on the basic variable in a direct and inversely proportional way, alternating themselves according to the environmental conditions occurred during the growth. Similarly, Mello et al. (2006) reported that the diameter of the stem directly relates itself to the tolerance of the plant to dry season, that is, stems with higher diameter are also more resistant to drought, probably because of the highest content of reserve compounds in those materials. Menezes et al. (2014) noted differentiated, direct and positive effect of the NS on the DMP between cuts performed.

The overall means of 1.68 and $1.69 \mathrm{~cm}$ for the first and second cuts confirm in this study (Table 6) the results stated by Oliveira et al. (2015), who observed a mean of $1.60 \mathrm{~cm}$ for the six elephant-grass genotypes fertilized with increasing doses of $\mathrm{N}$, which showed significant adjustments of first and second degrees linear models $(\mathrm{P}<$ 0.05). They reported that, this way, the diameter of the stem can be influenced by the nitrogen fertilization, since four of the six genotypes achieved regression to first degree level; this showed that when increasing the fertilization dose, the diameter of the stem will proportionally increase. On the contrary, it can be verified, in this work, that the DS was not influenced by the increasing of $\mathrm{N}$ in the fertilization, as most of the genotypes showed lack of regression; that explains the trait behavior in function of the doses of $\mathrm{N}$ applied. 
Table 5. Estimates of mean squares for the sources of variation due to the regression and the deviation of regression for the first degree linear models for diameter of stem (DS), concerning eight elephant-grass genotypes under different nitrogen $\left(\mathrm{N} 1=400, \mathrm{~N} 2=1000, \mathrm{~N} 3=1600 \mathrm{~kg} \mathrm{ha}^{-1}\right.$ of $\left.\mathrm{N}\right)$ and potassium doses $(\mathrm{K} 1=$ 200 and $\mathrm{K} 2=500 \mathrm{~kg} \mathrm{ha}^{-1}$ of $\mathrm{K}_{2} \mathrm{O}$ ) throughout two-year cultivation for energy purposes.

\begin{tabular}{|c|c|c|c|c|c|c|c|c|c|c|}
\hline \multirow{3}{*}{ Genotypes } & \multirow{3}{*}{$\mathrm{K}$ doses } & & \multicolumn{8}{|c|}{ DS } \\
\hline & & & \multicolumn{4}{|c|}{ First cut } & \multicolumn{4}{|c|}{ Second cut } \\
\hline & & & $\mathrm{DF}$ & $1^{\text {st }}$ Degree & $\mathrm{R}^{2}(\%)$ & Model & DF & 1st Degree & $\mathrm{R}^{2}(\%)$ & Model \\
\hline \multirow[t]{4}{*}{ Cubano de Pinda } & $\mathrm{K} 1$ & Reg & 1 & 1.200 & & - & 1 & 0.023 & & - \\
\hline & & Dev & 1 & $13.410^{*}$ & 8.19 & - & 1 & 0.002 & 91.92 & - \\
\hline & $\mathrm{K} 2$ & Reg & 1 & 0.500 & & - & 1 & 0.042 & & - \\
\hline & & Dev & 1 & 0.610 & 44.88 & - & 1 & 0.023 & 64.67 & - \\
\hline \multirow[t]{4}{*}{ Vruckwona } & $\mathrm{K} 1$ & Reg & 1 & 2.780 & & - & 1 & $0.224^{*}$ & & - \\
\hline & & Dev & 1 & 9.640 & 22.44 & - & 1 & 0.062 & 78.22 & 1 \\
\hline & $\mathrm{K} 2$ & Reg & 1 & 0.190 & & - & 1 & 0.017 & & - \\
\hline & & Dev & 1 & 0.029 & 86.56 & - & 1 & 0.058 & 22.79 & - \\
\hline \multirow[t]{4}{*}{ IAC-Campinas } & $\mathrm{K} 1$ & Reg & 1 & 0.032 & & - & 1 & 0.000 & & - \\
\hline & & Dev & 1 & 0.240 & 12.04 & - & 1 & 0.000 & 10.71 & - \\
\hline & $\mathrm{K} 2$ & Reg & 1 & 0.091 & & - & 1 & 0.015 & & - \\
\hline & & Dev & 1 & 1.060 & 7.89 & - & 1 & 0.010 & 58.23 & - \\
\hline \multirow[t]{4}{*}{ Capim Cana D’África } & $\mathrm{K} 1$ & Reg & 1 & 4.950 & & - & 1 & 0.015 & & - \\
\hline & & Dev & 1 & 1.650 & 75.00 & - & 1 & 0.017 & 46.26 & - \\
\hline & $\mathrm{K} 2$ & Reg & 1 & 0.576 & & - & 1 & 0.000 & & - \\
\hline & & Dev & 1 & 0.768 & 42.86 & - & 1 & 0.098 & 0.82 & - \\
\hline \multirow[t]{4}{*}{ Cameroon } & $\mathrm{K} 1$ & Reg & 1 & 0.580 & & - & 1 & 0.004 & & - \\
\hline & & Dev & 1 & 0.080 & 87.75 & - & 1 & 0.005 & 46.04 & - \\
\hline & $\mathrm{K} 2$ & Reg & 1 & 0.540 & & - & 1 & 0.009 & & - \\
\hline & & Dev & 1 & 0.131 & 80.38 & - & 1 & 0.033 & 22.11 & - \\
\hline \multirow[t]{4}{*}{ CPAC } & $\mathrm{K} 1$ & Reg & 1 & $20.350^{*}$ & & - & 1 & 0.046 & & - \\
\hline & & Dev & 1 & 1.810 & 91.82 & 1 & 1 & 0.063 & 42.39 & - \\
\hline & $\mathrm{K} 2$ & Reg & 1 & 0.060 & & - & 1 & 0.064 & & - \\
\hline & & Dev & 1 & 0.440 & 11.96 & - & 1 & 0.060 & 51.60 & - \\
\hline \multirow[t]{4}{*}{ IJ 7139} & $\mathrm{~K} 1$ & Reg & 1 & 1.090 & & - & 1 & 0.005 & & - \\
\hline & & Dev & 1 & 0.530 & 67.16 & - & 1 & 0.033 & 12.75 & - \\
\hline & $\mathrm{K} 2$ & Reg & 1 & 0.017 & & - & 1 & $0.375^{*}$ & & - \\
\hline & & Dev & 1 & 1.017 & 1.65 & - & 1 & 0.028 & 92.86 & 1 \\
\hline \multirow[t]{4}{*}{ BAG-86 } & K1 & Reg & 1 & 0.160 & & - & 1 & 0.048 & & - \\
\hline & & Dev & 1 & $0.880^{*}$ & 15.78 & - & 1 & 0.013 & 79.15 & - \\
\hline & $\mathrm{K} 2$ & Reg & 1 & 0.170 & & - & 1 & 0.028 & & - \\
\hline & & Dev & 1 & 2.470 & 6.67 & - & 1 & 0.002 & 91.95 & - \\
\hline
\end{tabular}

Note. $*$ = Significant at $5 \%$ level probability by $\mathrm{F}$ test. Overall mean for the DS- $1.68 \mathrm{~mm}$ (first cut) and 1.69 $\mathrm{mm}$ (second cut). 


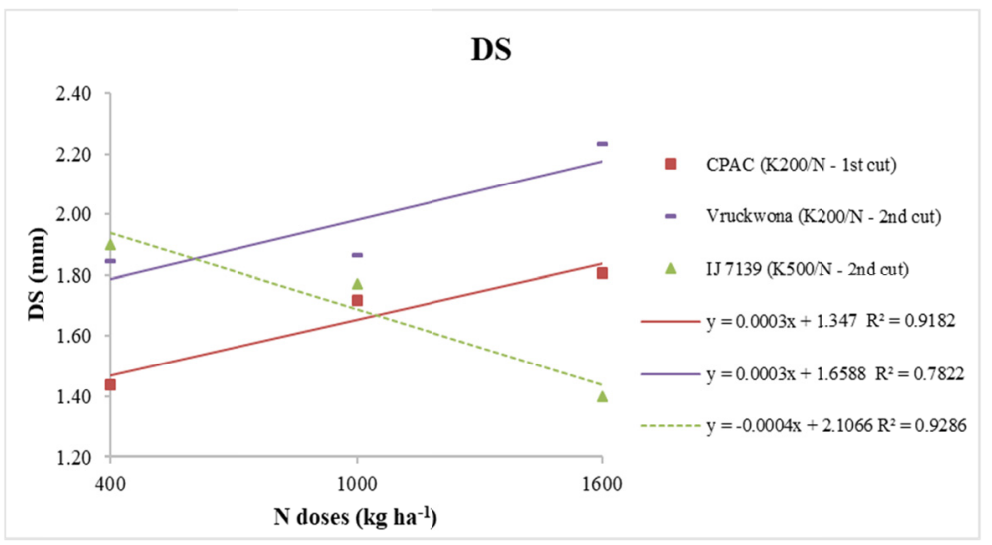

Figure 4. Regression lines for the DS trait of genotypes that showed adjustment of first line linear model according to study of the increasing doses of $\mathrm{N}\left(400,1000\right.$, and $1600 \mathrm{~kg} \mathrm{ha}^{-1}$ of $\left.\mathrm{N}\right)$ within the dose $200 \mathrm{~kg} \mathrm{ha}^{-1}$ of $\mathrm{K}_{2} \mathrm{O}$ in the cut $1(\mathrm{G} 6-\mathrm{CPAC})$ and cut 2 (G2-Vruckwona) and within the dose $500 \mathrm{~kg} \mathrm{ha}^{-1}$ of $\mathrm{K}_{2} \mathrm{O}$ (G7- $\mathrm{IJ}$ $7139)$ in the cut 2

\section{Conclusions}

For the Capim Cana D'África (G4), CPAC (G6), and IJ 7139 (G7) genotypes, the adjustment of first degree linear model of the regression indicates that the increasing of $\mathrm{N}$ in fertilization had a negative influence on the DMP.

Concerning the NT and HEI traits, the regression analysis revealed that, for the CPAC (G6) genotype, with respect to the NT, and for the Cana D'Africa (G4) and CPAC (G6) genotypes, in relation to the HEI, the response according to the increase of $\mathrm{N}$ in the fertilization was directly proportional.

For the DS, the CPAC (G6) and Vruckwona (G2) genotypes indicated a directly proportional response to the increasing of the doses of $\mathrm{N}$, and the IJ 7139 (G7) genotype confirmed an inversely proportional response.

The results are very promising and confirm the use of the eight elephant-grass genotypes as an alternative source for biomass production.

\section{References}

Almeida, B. O., Daher, R. F., Novo, A. A. C., Gravina, G. A., Vivas, M., Moraes, C. R. de O., ... Silva, V. B. (2016). Effect of nitrogen and potassium fertilizations on elephant grass genotypes used for energy purposes in Northern Rio de Janeiro State, Brazil. African Journal of Agricultural Research, 11, 5043-5049. https://doi.org/10.5897/AJAR2016.11636

Andrade, A. C., Fonseca, D. M., Queiroz, D. S., Salgado, L. T., \& Cecon, P. R. (2003). Adubação nitrogenada e potássica em capim-elefante (Pennisetum purpureum Schum. Cv. Napier). Ciência e Agrotecnologia, 1643-165.

Barreto, G. P., Lira, M. D. A., Santos, M. V. F. D., \& Dubeux Júnior, J. C. B. (2001). Avaliação de clones de capim-elefante (Pennisetum purpureum Schum.) e de um híbrido com o milheto (Pennisetum glaucum (L.) R. Br.) submetidos a estresse hídrico. Revista Brasileira de Zootecnia, 30(1), 1-6. https://doi.org/10.1590/ S1516-35982001000100001

Bonfim-da-Silva, E. M., \& Monteiro, F. A. (2006). Nitrogênio e enxofre em características produtivas do capim-braquiária proveniente de área de pastagem em degradação. Revista Brasileira de Zootecnia, 35(4), 1289-1297. https://doi.org/10.1590/S1516-35982006000500006

Borges, L. S., Aquino, F. C., \& Evangelista, A. F. (2016). Potencial do capim elefante para geração de bioenergia - revisão. Nutritime Revista Eletrônica, 13(1), 4518-4523.

Botrel, M. A., Pereira, A. V., \& Freitas, V. P. (2000). Potencial forrageiro de novos clones de capim-elefante. Revista Brasileira de Zootecnia, 29(2), 334-340. https://doi.org/10.1590/S1516-35982000000200003

Cruz, C.D. (2013). GENES-A Software Package for Analysis in Experimental Statistics and Quantitative Genetics. Acta Scientiarum. Agronomy, 35, 271-276. https://doi.org/10.4025/actasciagron.v35i3.21251

Cruz, R. S., Santos, A. C., Castro, J. G. D., Alexandrino, E., Caraça, D. C., \& Diniz, J. P. (2010). Produtividade 
do Capim-Cameroon estabelecida em duas classes de solos e submetido a doses crescentes de nitrogênio no norte tocantinense. Acta Scientiarum. Animal Sciences, 32(4), 393-399. https://doi.org/10.4025/ actascianimsci.v32i4.6209

Daher, R. F., Pereira, A. V., Pereira, M. G., Ledo, F. J. S., Amaral Júnior, A. T., Rocabado, J. M. A., ... Tardin, F. D. (2004). Análise de trilha de caracteres forrageiros do capim-elefante (Pennisetum purpureum Schum.). Ciência Rural, 34(5), 1531-1535. https://doi.org/10.1590/S0103-84782004000500032

Embrapa-Centro Nacional de Pesquisa de Solos. (2013). Sistema brasileiro de classificação de solos. Rio de Janeiro: Embrapa Solos.

Freire, L. F., Baliero, F. C., Zonta, E., Anjos, L. H. C., Pereira, M. G., Lima, E., ... Polidoro, J. C. (2013). Manual de Calagem e Adubação do Estado do Rio de Janeiro. Rio de Janeiro: UFRRJ e Embrapa.

Köppen, W. (1948) Climatologia: Con um estúdio de los climas de La Tierra. México: Fondo de Cultura Economica,

Marafon, A. C., Camara, T. M. M., Santiago, A. D., \& Rangel, J. H. (2010). Potencial do capim-elefante para produção de energia renovável. Retrieved from http://www.diadecampo.com.br/zpublisher/materias/ Newsletter.asp?id $=27636 \&$ secao $=$ Artigos\%20Especiais

Mckendry, P. (2002). Energy Production from Biomass (Part 1): Overview of Biomass. Bioresource Technology, 83, 37-46. https://doi.org/10.1016/S0960-8524(01)00118-3

Mello, A. C. L., Lira, M. A., \& Dubeux Júnior, J. C. B. (2006). Degradação ruminal da matéria seca de clones de capim-elefante em função da relação folha/colmo. Revista Brasileira de Zootecnia, 35(4), 1316-1322. https://doi.org/10.1590/S1516-3598200600050000

Mendonça, J. F. B., \& Rocha, G. P. (1985). Rendimento do capim-elefante (Pennisetum purpureum cv. Cameroom) em diferentes idades de corte. Ciência Prática, 9(1), 23-29.

Menezes, B. R. S., Daher, R. F., Gravina, G. A., Amaral Junior, A. T., Oliveira, A. V., Schneider, L. S. A., \& Silva, V. B. (2014). Correlações e análise de trilha em capim-elefante para fins energéticos. Agrária, 9, 465-470. https://doi.org/10.5039/agraria.v9i3a3877

Mohammed, I. Y., Abakr, Y. A., Kazi, F. K., Yusup, S., Alshareef, I., \& Chin, S. A. (2015). Comprehensive Characterization of Napier Grass as a Feedstock for Thermochemical Conversion. Emergies, 8, 3403-3417. https://doi.org/10.3390/en8053403

Monteiro, F. A. (1994). Adubação para estabelecimento e manutenção de capim elefante. In M. M. Carvalho, M. J. Alvim, D. F. Xavier, \& L. A. Carvalho (Eds.), Capim-elefante, produção e utilização (pp. 49-79). Coronel Pacheco, Embrapa CNPGL.

Morais, R. F., Quesada, D. M., Reis, V. M., Urquiaga, S., Alves, B. J. R., \& Boddey, R. M. (2011). Contribution of biological nitrogen fixation to Elephant grass (Pennisetum purpureum Schum.). Plant and Soil, 349, 1-12. https://doi.org/10.1007/s11104-011-0944-2

Novo, A. A. C., Daher, R. F., De Amaral Gravina, G., Costa, E. S., Ogliari, J., Araújo, K. C., ... Silva, V. B. (2016). Effect of nitrogen and potassium fertilization on morpho-agronomic traits of three elephant grass (Pennisetum purpureum Schum.) genotypes for biomass production. African Journal of Biotechnology, 15(43), 2411-2423. https://doi.org/10.5897/AJB2016.15615

Oliveira, A. V., Daher, R.F., Menezes, B. R. S., Souza, L. B., Gonçalves, A. C. S., \& Oliveira, M. L. F. (2013). Avaliação do desenvolvimento e de características morfoagronômicas e qualidade de biomassa energética de 73 genótipos de capim-elefante em Campos dos Goytacazes-RJ. Boletim da Industria Animal, 70, 119-131. https://doi.org/10.17523/bia.v70n2p119

Oliveira, É. S., Daher, R. F., Ponciano, N. J., Gravina, G. A., Sant'ana, J. A. A., Gottardo, R. D., .. Novo, A. A. C. (2015). Variation of Morpho-Agronomic and Biomass Quality Traits in Elephant Grass for Energy Purposes According to Nitrogen Levels. American Journal of Plant Sciences, 6, 1685-1696. https://doi.org/10.4236/ajps.2015.611168

Quesada, D. M., Boddey, R. M., Reis, V. M., \& Urquiaga, S. (2004). Parâmetros qualitativos de genótipos de capim-elefante (Pennisetum purpureum Schum.) estudados para a produção de energia através da biomassa. Circular Técnica 8. Seropédica, RJ, Brazil.

Santos, E. A., Silva, D. S., \& Queiroz Filho, J. L. (2001). Perfilhamento e algumas características morfológicas do capim-elefante cv. Roxo sob quatro alturas de corte em duas épocas do ano. Revista Brasileira de 
Zootecnia, 30(1), 24-30. https://doi.org/10.1590/S1516-35982001000100005

Santos, M. M. P., Daher, R. F., Ponciano, N. J., Gravina, G. A., Pereira, A. V., \& Santos, C. L. (2014). Respostas do Capim-elefante sob Doses de Adubação Azotada de Cobertura para Fins Energéticos. Revista de Ciências Agrárias, 37, 100-108.

Santos, R. L., Azevedo, V. M., Freire, F. J., Rocha, A. L., Tavares, J. A., \& Freire, M. B. G. S. (2012). Extração e eficiência de uso de nutrientes em capim elefante na presença de gesso. Revista Brasileira de Ciência do Solo, 36(2), 497-505. https://doi.org/10.1590/S0100-06832012000200019

Tcacenco, F. A., Botrel, M. D. A., Carvalho, M., Alvim, M. J., Xavier, D. F., \& Carvalho, L. D. A. (1994). Identificação e avaliação de acessos e cultivares de capim-elefante.

Vitor, C. M. T., Fonseca, D. M. D., Cóser, A. C., Martins, C. E., Nascimento Júnior, D. D., \& Ribeiro Júnior, J. I. (2009). Dry matter production and nutritional value of elephant grass pasture under irrigation and nitrogen fertilization. Revista Brasileira de Zootecnia, 38, 435-442. https://doi.org/10.1590/S1516-359820090003 00006

\section{Copyrights}

Copyright for this article is retained by the author (s), with first publication rights granted to the journal.

This is an open-access article distributed under the terms and conditions of the Creative Commons Attribution license (http://creativecommons.org/licenses/by/4.0/). 